opinion. having regard to any wishes expressed by relatives of the patient or any other relevant circumstances, that it is necessary or proper for the application to be made by him.

I think that it is clear that 5.54 (1) does require a mental welfare officer to use his own judgment in deciding whether he should make an application in respect of a patient for his admission to hospital.

It follows that the functions of a mental welfare officer under the 1959 Act are wider than merely ensuring that the requirements of the Act relating to applications have been complied with but include the exercise of his judgment as to whether, having regard to all the circumstances, including the contents of the medical recommendations it is, in the words of s.54 (1) 'necessary or proper' for him to make the application. A social worker must accept the diagnosis of the patient's medical disorder set out in the medical recommendations; but he is entitled to take the view in a particular case that it is not appropriate to make an application.
In the hypothetical case suggested, I do not think that a psychiatrist would be held to be liable in an action in negligence, and in any event I think that he would be protected by s. 141 of the 1959 Act. I think that it is most unlikely that the High Court would give leave to take proceedings against the psychiatrist under s.141 (2) of the Act.

The College will continue to press for more stringent criteria to be adopted for the appointment of Mental Welfare Officers. and we have been informed that these and related matters are under discussion at the DHSS.

\section{G. C. TImbURY Registrar}

The new Mental Health (Amendment) Bill (to be summarized next month) provides for the appointment of (psychiatrically) competent social workers-GCT.

\title{
College Library
}

The Librarian wishes to thank those Members who have generously donated books to the library during the past six months, particularly the following who have given copies of their published works.

Dr P. Barker: Basic Family Therapy

Dr S. Bloch: Psychiatric Ethics

Dr John Bowlby: Psychoanalysis as a Natural Science

Prof B. G. Burton-Bradley: Stone Age Crisis

Prof A. H. Crisp: Anorexia Nervosa: Let Me Be

Dr S. E. Greben: A Method of Psychiatry

Dr J. G. Howells: Modern Perspectives in the Psychiatry of Middle Age

Dr J. Jancar: Research at Stoke Park

Prof M. Lader: Handbook of Biological Psychiatry Introduction to Psychopharmacology

Dr H. P. Laughlin: The A.C. Psych. Archives

Dr M. Little: Transference Neurosis and Transference Psychosis: Toward Basic Unity
Prof I. Marks: Cure and Care of Neuroses

Dr B. Morris: Handbook of Psychiatric Rehabilitation

Dr J. E. Oliver: Severely Ill-Treated Young Children in North East Wiltshire

Dr R. L. Palmer: Electroconvulsive Therapy: An Appraisal

Prof E. S. Paykel: Monoamine Oxidase Inhibitors: the State of the Art

Dr D. A. A. Primrose: Proceedings of the International Association for Scientfic Study of Mental Deficiency

Dr D. Richter: Addiction and Brain Damage

Dr W. Sargant: The Unquiet Mind

Prof K. Singer: The Prognosis of Narcotic Addiction

Dr A. C. Tait: Chronicle of Crichton Royal (by G. Turner)

Dr D. Wheatley: Stress and the Heart

Prof. J. K. Wing: Rehabilitation of Patients with Schizophrenia and with Depressions

What is a Case?

\section{Research Committee: Free Advice}

The Research Committee of the College has recently produced a beginner's guide on understanding clinical research in psychiatry, entitled 'Hints on Research'. Copies of the leaflet have been distributed to psychiatric tutors, but it is also available free on direct request from Miss Jane Boyce at the College. It offers advice on choosing a subject, drawing a plan of action and getting help, including library aid and funds. 